\title{
Practical Self-Defense Program for Children Using 4P (Pray, Prediction, Preventive, and Protective) Concept:
}

\author{
An Effort to Improve Self-Control
}

\author{
Muhammad Nur Alif*, Tatang Muhtar, Rizal Ahmad Fauzi \\ Primary School Physical Education \\ Universitas Pendidikan Indonesia \\ Bandung, Indonesia \\ *mnalif@upi.edu, tatangmuhtar@upi.edu, rizalafauzi13@upi.edu
}

\begin{abstract}
This research aimed to find out the effects of practical self-defence training on the improvement of self-control in children at a certain age. The method used was the experimental research method with Randomized Pre-test Posttest Control Group Design. The instrument used was the selfcontrol questionnaire from Liebling. The research was conducted in one of the cities in West Java Province. The population in this study were children aged 11-13 years. The results showed that practical self-defence training had a positive effect on self-control in children, and children who were treated with learning and understanding the concepts of self-defence performed better selfcontrol than children who were not treated with practical selfdefence. However, the results of self-control tests on samples of girls did not show a significant improvement. For some reasons, girls have better self-control compared to boys.
\end{abstract}

Keywords: program, training, self-defense, self-control

\section{INTRODUCTION}

Learning the basic skills of self-defence is a necessity for children. It is an obligation for teachers, parents, and the wider community to provide an understanding of the concept of selfdefence itself, because they may encounter an event that threatens their safety and others'. Children must be equipped with the ability to recognize dangerous situations and face unwanted events. In learning and mastering self-defence skills, children can build self-confidence based on the fact that children can set goals and have thoughts about the things needed to achieve the goals at the next level [1].

Self-defence is needed by human beings to live free from threats and without fear of danger. Safety needs are the second level of needs [2]. Safety needs are activated after physiological needs are met. They refer to the need for a secure working environment, free from any threats or harms. The rationale is that employees working in an environment free of harm do their jobs without fear of harm. Therefore, selfdefence becomes a necessity that must be fulfilled. Selfdefence instruction has been defined as preparation to minimize the possibility of becoming a victim of crime through the acquisition of a small number of simple, yet effective, survival skills [3]. Based on the statement, children must prepare self-defence to minimize the possibility of becoming a victim of crime through a simple but effective self-defence ability. The rapid development of science and technology gives various impacts on human survival. Globalization has brought many changes in every aspect of life. The changes that underlie the importance of self-control include computer revolution, education revolution, materials revolution, sexual revolution, family revolution and violence revolution [4]. When these rapid changes occur, children need to have self-control so that they are able to control every behaviour and can choose whether something is permissible or not.

The development of self-control is inseparable from high self-awareness of the abilities a person has. When coming to age, children to teenagers or adolescents, self-control ability develops along with emotional maturity [5]. Teenagers are said to have reached emotional maturity when, at the end of adolescence, their emotions do not explode in front of other people. Instead, they wait for a more appropriate time and place to express their emotions in ways that are more acceptable for other people [6]. Children's self-control ability is determined by how much and to what extent they try to enhance self-control. The ability of self-control can direct their own behaviour, namely an action that is concerned with the ability to pursue a desire with a directed purpose. The ability of self-control in children is very different from adults' because children and adults have different levels of aggressiveness $[2,7]$. Within a person there is a self-regulation system that focuses on self-control [4]. This self-control process explains how a person can control his or her behaviour in living life according to one's abilities. A study Duckworth, Quinn \& Tsukayama, stated that self-control is very helpful for everyone, especially children because self-control helps children to learn to solve problems, to be able to complete their homework and to behave positively in the classroom or wherever the child is [8].

Self-control is also very important to be able to make better decisions. As an example, in the case of a selfish person versus a proportional person, a selfish teenager can be more dominant 


\section{METHODS}

in a group so that he or she looks more prominent than other friends. If the teenager has good self-control and can activate positive thoughts, the teenager will not show off, but rather highlight collaboration in the group [9]. It is known that physical education and sports teach children about how to maintain fitness and encourage a healthy lifestyle. Exercise is not only important for the health of the body, but also for the development of attitudes and knowledge for children. By carrying out sports activities, one can understand oneself thoroughly both in terms of attitude, knowledge, and physical condition. Research related to this matter was issued by Tel Aviv University in which they managed to find a link between exercise and cognitive, emotional, and behavioural factors in children. Keren Shahar from Tel Aviv University said that exercise can help improve self-control and discipline to reduce feelings of aggression in children [10]. This research was presented at the TAU's Renata Adler Memorial Research Centre for Child Welfare and Protection Conference. Every sports game has different characteristics in developing the character of children's who participate in it. One of the sports activity that emphasizes character development is self-defence. In this case, self-defence is an art that arises due to human needs to defend themselves in a fight.

The self-defence referred to in this study is self-defence learning that is packaged in a practical manner and so far there has been no research results related to the influence of practical self-defence [3,7]. This means that it is not classified into one particular type of self-defence branches such as Silat, karate, taekwondo and others. The concept of the movement presented is quite similar to everyday movements. In self-defence, several body parts that can be used as weapons. "Fingers, fingernails, head, feet, elbows, knees, and even hips apparently has a variety of weapons that are quite deadly when used correctly and precisely" [11]. There are also simple media that can be used as weapons such as a credit/ATM card, pen, pencil, lipstick, umbrella, comb, key, and bag. The use of these various weapons needs to be balanced with the knowledge of the 4P concept, namely Pray, Prediction, Preventive, and Protection. Self-defence learning can be followed by children through simple but deadly movements so that the learning can be easily accepted by them. The learning includes the three physical education domains, namely psychomotor, cognitive, and affective, which are important parts of the life process.

Some researches related to the effect of self-defence to several physiological aspects have been done by Ball and Liebling. Ball stated that the women in the self-defence and karate courses increased their self-defence, self-control and reduced their fear [3]. It assumes that self-defence for women may develop their self-efficacy. Meanwhile, Liebling believed that self-defence training led to education in fear of crime (both personal and property) and an increase in self-defence selfcontrol. As it is stated, self-defence training program has, for some extends, greater effect toward self-efficacy compared to fear of crime, avoidance behaviour and anxiety. Nevertheless, only a few research relates the self-defence to children selfcontrol. For those reasons, this paper analysed the effect of self-defence programme to increase children self-control.

\section{Research Procedures}

\section{A. Research Design}

The method used in this study was the experimental method with Randomize Pre-tests Post-test Control Group Design [12].

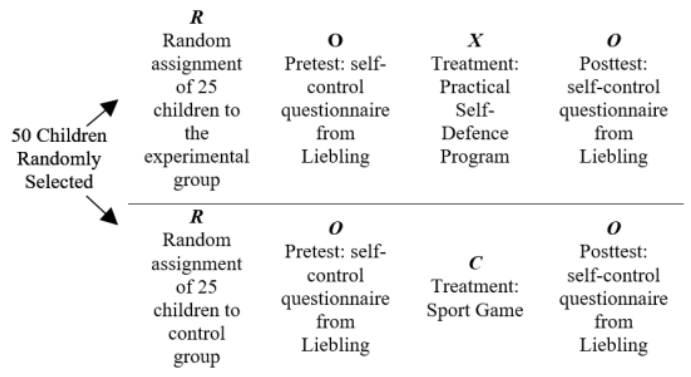

Fig. 1. The randomized pretest-posttest control group design.

\section{B. Population and Sample}

The population in this study were children aged $11-13$ years in Sumedang City. The samples used in this study were 50 children with random sampling technique. Before treatment, the level of self-control in the samples was first tested using a self-control questionnaire [3]. After 8 meetings the samples were tested again using the same questionnaire.

- The population for this research were grouped into two (experiment and control)

- The pre-test was given to the samples

- The program was applied to the experimental group.

- The post-test was given to both groups.

- The data was gathered and analysed.

- Drawing the result of the research based on the finding.

\section{Data Analisis}

After self-control data had been gathered, the statistic equation was applied as follow:

- SPSS was used to calculate the average, standard of deviation and normal distribution using KolmogorovSmirnov.

- Homogeneity of variance was applied using Levene Statistic. This test aimed to check sample homogeneity.

- Hypothesis testing was checked using independent sample t-test with degree of freedom in 0.05 .

\section{RESULTS AND DISCUSSION}

\section{A. Results}

The results of data processing and analysis are presented as follows. There was a significant influence of the application of practical self-defence program on children's self-control and Children who were given practical self-defence learning had 
In learning the concept of self-defence, children tend to higher self-control than children who were not given practical self-defence learning. The improvement of the experimental group's self-control is presented in Table 1 .

TABLE I. RESULTS OF SELF-CONTROL IN EXPERIMENT GROUP

\begin{tabular}{|c|c|c|c|c|c|c|}
\hline $\begin{array}{c}\text { Experiment } \\
\text { Group }\end{array}$ & N & Sum & Mean & $\begin{array}{c}\text { Standard } \\
\text { Deviation }\end{array}$ & Sig & $\begin{array}{c}\text { R } \\
\text { Square }\end{array}$ \\
\hline $\begin{array}{l}\text { Pretest Self } \\
\text { control }\end{array}$ & 2 & 1540 & 102,67 & 2,41 & 0,00 & 0,670 \\
\hline $\begin{array}{l}\text { Postest Self } \\
\text { control }\end{array}$ & 5 & 1681 & 112,07 & 2,37 & 0,001 & 0,670 \\
\hline
\end{tabular}

The probability value (Sig.) $0,000<0.05$ was calculated and then $\mathrm{HO}$ is rejected. Thus, it can be concluded that there was a significant influence of the application of practical selfdefence learning on children's self-control. The value of $r$ square shows a significant increase in self-control by $67 \%$. To find out the difference between the experimental group and the control group, the similarity tests were used between the two groups. The following similarity test tables are two averages.

TABLE II. RESUltS OF DIFFERENCE TEST (T-TEST) GAIN SELFCONTROL EXPERIMENT GROUP AND CONTROL GROUP

\begin{tabular}{|l|l|l|l|l|l|}
\hline \multirow{2}{*}{ No } & \multicolumn{1}{|c|}{ Group } & \multicolumn{3}{|c|}{ Self-control } & \multirow{2}{*}{ Sig. } \\
\cline { 3 - 5 } & & $\begin{array}{c}\text { Mean } \\
\text { Pre-test }\end{array}$ & $\begin{array}{c}\text { Mean } \\
\text { Post-test }\end{array}$ & $\begin{array}{c}\text { Mean } \\
\text { Gain }\end{array}$ & \\
\hline 1 & $\begin{array}{l}\text { Experiment (Practical } \\
\text { Martial Art Learning) }\end{array}$ & 102,67 & 112,07 & 9,40 & \multirow{2}{*}{0,014} \\
\hline 2 & $\begin{array}{l}\text { Control (Conventional } \\
\text { Learning) }\end{array}$ & 101,80 & 108,73 & 6,93 & \\
\hline
\end{tabular}

The probability value (Sig.) $0.014<0.05$ was calculated and then H0 was rejected. Thus, it can be concluded that there was a difference in influence on self-control between children who were given practical self-defence learning with children who were not given practical self-defence learning. It can be seen from the average results of the two groups. The self-control scores of children who were given self-defence learning were greater than the scores of children who were not given selfdefence learning.

\section{B. Discussion}

Based on observations in the field, the dominant learning material capable of improving the children's self-control was found. The material is all the material for self-defence practice in the practical self-defence concept learning program especially when the children were faced with examples of criminal cases. Self-control is driven by behaviour and automatic impulsive impediment when responding strong emotion toward uneasy experience [13]. If it happens every day, this core physiological process is related to positive life [13]. When children were faced with the examples, they were required to read their own condition and the situation of their environment in order to avoid mistakes in carrying out an action. This is one part of the $4 \mathrm{P}$ concept, namely prediction. Reading the situation is an important part of controlling appropriate behaviour for themselves and others. avoid things that will endanger them, such as fights, brawls, and negative things that will harm others [3,12]. This is because, in the learning process, children must really appreciate everything that is in their lives. An in-depth view of self-defence that it's learning is a mastery of techniques, polishing courage, politeness, and self-control so that it ignites from within and becomes a light that guides actions in everyday life. Since in the basic concept of self-defence, children are taught to be able to control emotions and accept themselves and others as they are, they should be able to enhance existing achievements and be able to be responsible for what has been done [14].

Self-control is sometimes used to more specifically describe the morally-driven, deliberate inhibition of unwanted behavioural responses [15]. It can be said that self-control can be gained through practical self-defence learning which teaches children to be able to comprehend themselves thoroughly both in terms of attitudes, knowledge, gestures and their own body condition especially in reading situations of themselves and the surrounding environment. It is then supported by fitness training which is part of physical education goals that are positively correlated with one's self-control. This is in line with the research conducted "Self-control strength and physical exercise: An ecological momentary assessment study" with the results that "multilevel analyses revealed that the level of selfcontrol strength was positively associated with physical exercise $(p=0.01)$, and this relationship was stronger in individuals with low trait self-control than in those with high trait self-control (interaction effect: $p=0.03$ ) [14].

Her research found that there was a positive relationship between one's good fitness and self-control. This research found that the most dominant difference was seen in selfdefence practice learning materials. When the experimental group was faced with an example of a criminal case, they read their own situation and their environment more quickly and then took appropriate action when they were threatened so that they did not harm themselves. This occurred because, before the material in the self-defence practice, the experimental group had been given explanations about the true concept of self-defence and the development of the right mind-set when faced with a threat of crime. In contrast, the control group were slower in reading their own situation and their environment when faced with examples of criminal cases. This happened because the control group in the learning process was not given the concept of self-defence. Reading the situation and the environment to then take appropriate actions in resolving a confronted event is an integral part of one's self-control [17].

\section{CONCLUSION}

Based on the results of research and discussion, it can be concluded that a practical self-defence program for children can significantly increase the level of self-control. A practical self-defence program can also contribute and provide solutions to problems that have been described before, namely preventing the impact of scientific progress due to inevitable globalization on children's attitudes and behaviours in controlling themselves. But the results of self-control tests on 
[7] L.B. Shaffer, An Application Of Physical Feminism TheoryTo Women's Gender Role And Self-defence Training. ProQuest Information and Learning Company, 2004.

some extents, girls have better self-control compared to boys.

\section{REFERENCES}

[1] G.D. Walters, Are behavioral measures of self-control and the Grasmick self-control scale measuring the same construct? A meta-analysis. American journal of criminal justice, vol. 41(2), pp. 151-167, 2016.

[2] A. Maslow, "Implications for Human Resource Management in the Secondary School System in Rivers State", Journal of Curriculum and Teaching, vol 2(1), 2013.

[3] D.E. Liebling, "Effects of a Self-defence Training Program on Women's Fear of Crime, Avoidant Behavior, Self-Efficacy, and General Anxiety,' J. Child Fam Stud, 2014, vol. 23, pp.124-136, 2006.

[4] S. Henschel, M. de Bruin, and E. Möhler, "Self-control and child abuse potential in mothers with an abuse history and their preschool children," Journal of Child and Family Studies, vol. 23(5), pp. 824-836, 2014.

[5] M. Mark, P. Greg, and S. Dikla, "Self-control Depletion and the General Theory of Crime," J Quant Criminol, vol. 22, pp.263-277, 2006.

[6] D.P. Mears, J.C. Cochran, and K.M. Beaver, "Self-control theory and nonlinear effects on offending," Journal of Quantitative Criminology, vol. 29(3), pp. 447-476, 2013.

[8] Q. Duckwort, "Investigating Friendship Quality: An Exploration of SelfControl and Social Control Theories' Friendship Hypotheses," Journal Springer Science\&Business Media, vol. 42, no. 6, pp. 578-86, 2011.

[9] J.H. Boman, M.D. Krohn, C.L. Gibson, and J.M. Stogner, "Investigating friendship quality: An exploration of self-control and social control theories' friendship hypotheses," Journal of youth and adolescence, vol. 41(11), pp. 1526-1540, 2012.

[10] D.P. Mears, J.C. Cochran, and K.M. Beaver, "Self-control theory and nonlinear effects on offending," Journal of Quantitative Criminology, vol. 29(3), pp. 447-476, 2013

[11] E. Hendrawan, Women Self-defence Of Kushin Ryu, Jakarta: PT Gramedia Widiasarana, 2011.

[12] J.R.Fraenkel and N.E. Wallen, How To Design And Evaluate Research in Education, USA: McGraw Hill, Inc., 2012.

[13] C.L. Kelly, S.I. Sünram-Lea, and T.J. Crawford, "The role of motivation, glucose and self-control in the antisaccade task," PloS one, vol. 10(3), pp. e0122218, 2015.

[14] J.B. Sujoto, Teknik Oyama Karate Seri Kihon, Jakarta: Elex Media Komputindo, 2002.

[15] R.D. Forkner, "The Effects Of Self-Control And Social Connection On Recidivism," ProQuest Information and Learning Company, 2010.

[16] A. Schöndube, A. Bertrams, G. Sudeck, and R. Fuchs, "Self-control strength and physical exercise: An ecological momentary assessment study," Psychology of sport and exercise, vol. 29, pp. 19-26, 2017.

[17] N. Edward, "Self-Control Scale AS-36: Construction and validation study," Polish Psychological Bulletin, vol. 46(3), pp. 488-497, 2015. 